Research article

\title{
EFFECT OF SUNFLOWER, LINSEED AND SOYBEAN MEAL IN PIG DIET ON CHEMICAL COMPOSITION, FATTY ACID PROFILE OF MEAT AND BACKFAT, AND ITS OXIDATIVE STABILITY
}

\author{
ĐORĐEVIĆ Vesna ${ }^{1 *}$, ĐORĐEVIĆ Jasna ${ }^{2}$, BALTIĆ Ž. Milan ${ }^{2}$, LAUDANOVIĆ \\ Milica $^{2}$,TEODOROVIĆ Vlado ${ }^{2}$, BOŠKOVIĆ Marija ${ }^{2}$, PEURAČA Mile ${ }^{3}$, MARKOVIĆ \\ Radmila ${ }^{2}$
}

${ }^{1}$ Institute of Meat Hygiene and Technology, Belgrade, Serbia; ${ }^{2}$ Faculty of Veterinary Medicine, University of Belgrade, Belgrade, Serbia; ${ }^{3}$ AD Napredak, Stara Pazova, Serbia

(Received 15 April; Accepted 13 July 2016)

\begin{abstract}
The aim of this study was to examine the effect of added sunflower, linseed or soybean meal to a standard pig fattening diet on the chemical composition, fatty acid profiles of meat and backfat, and on the oxidative stability of backfat from pigs. The content of saturated (SFA) and monounsaturated fatty acids (MUFA) was significantly lower $(P<0.01)$, while content of polyunsaturated fatty acids (PUFA) was significantly higher $(P<0.01)$ in the diet with added linseed. The feeding study was conducted on 30 pigs, with groups of 10 pigs fed one of the three different diets for 46 days before slaughter. There were no differences in the chemical composition (protein, water, fat, minerals) of meat from pigs fed the different diets. The content of SFA and MUFA was significantly higher, while the average PUFA content was significantly lower $(P<0.01)$ in meat and backfat of pigs fed diet with added linseed. The content of $n-6$ fatty acids was significantly lower and n-3 fatty acids significantly higher, with more desirable n-6/n-3 ratio, in meat and backfat of pigs fed diet with added linseed. Malondialdehyde in the backfat of pigs fed diet with added linseed was significantly lower than that in the other two diet groups after the tissue was stored frozen at $-20^{\circ} \mathrm{C}$ for $3,6,9$ and 12 months.
\end{abstract}

Key words: pigs, oilseeds, fatty acids, backfat, meat

\section{INTRODUCTION}

The human body cannot produce essential fatty acids, but it has the ability to convert the main essential fatty acids from food into long-chain polyunsaturated fatty acids (PUFA), which have a specific role in the body. Research has confirmed that the increased intake of n-3 fatty acids can decrease the risk of heart disease incidence and vascular disorders, but also can improve the clinical features of some autoimmune and inflammatory disorders [1]. Furthermore, n-3 fatty acids decrease blood pressure,

\footnotetext{
*Corresponding author: e-mail: vesna@inmesbgd.com
} 
regulate activity of protein kinase $\mathrm{C}$, which play a role in angiogenesis and slow growth and dissemination of tumour metastases [2,3]. Also, n-3 fatty acids are recognized as an important nutritional factor for brain function and development, and their deficit, in the prenatal period, can change learning ability, memory and behaviour [4]. There is evidence that decosahexaenoic acid is essential for normal functioning of rhodopsin, and therefore visual function. Beside quantity, the ratio of two groups of PUFA, n-6 fatty acids (formed from linoleic acid; LA; - C18:2 n-6) and n-3 fatty acid (formed from alfa linolenic acid; ALA; - C18:3 n-3) influences human cardiovascular and other chronic diseases [1,5-7]. It is recommended that the total human dietary intake of lipids should be $30 \%$ of total energy intake, and about $10 \%$ of lipid energy should be from saturated fatty acids (SFA), while $10 \%$ to $20 \%$ should be from PUFA. The recommendation is for a ratio of less than 4 [8]. Consumer interest for $n-3$ enriched products is constantly increasing because of their potential health benefits (in modern human diets, the ratio of $n-6 / n-3$ PUFA is very high, 10- 15:1 and optimum is 4:1), which is the reason why production of pork products enriched with $n-3$ fatty acid is of interest for many manufacturers. The recommended daily intake (RDA) of n-3 fatty acid in the diet of adult males is $1.6 \mathrm{~g}$, and $1.1 \mathrm{~g}$ for adult females [9-11]. In monogastric animals, including pigs, fatty acids from feed are absorbed from the gastrointestinal tract with small changes. In general, the fatty acid profile of meat directly reflects the fatty acid profile in the pig diet [12]. Fatty acids of the n-3 series are especially common in soybeans, linseed and fish lipid of the northern seas fish, while n- 6 fatty acids are found in oilseed plants, seeds and nuts. Many pig producers include soy, sunflower, linseed or other oilseeds that contain n-3 and n-6 fatty acids, in swine finisher diet, in order to improve the fatty acid composition of meat and fat [13].

The aim of this study was to examine the effect of different sources of fatty acids, sunflower, linseed and soybean meal, in pig diet on fatty acid and chemical composition of meat and fatty acid composition and oxidative stability (content of malondialdehyde - MDA) of backfat.

\section{MATERIAL AND METHODS}

\section{Animal, housing and trials}

The study was conducted on 30 pigs (50\% barrows and 50\% gilts), of the same origin, Yorkshire x Landrace crossbreeds, with initial body weight of $60 \mathrm{~kg}$. Animals were randomly allocated to one of three dietary treatments and housed in a finishing facility, on partially slatted floors, in groups of 10 animals per pen (stocking density $=1 \mathrm{~m}^{2}$ / pig). Pigs were provided with ad libitum feed and water. The trial was conducted over a 46 day period, when animals were exposed to their respective experimental diets, with finished animal weights ranging from 100 to $110 \mathrm{~kg}$. 


\section{Experimental diets}

From the start of the trial animals were fed for 46 days one of the three experimental diets. These comprised the same standard mixture [14] for the final fattening of the pigs (finisher diet), formulated to meet the maintenance and growth requirements of animals used in this study, but which differed in the addition of oilseeds only. The experimental group I (E-I) diet contained added sunflower seed, the experimental group II (E-II) diet contained added commercially prepared linseed (Vitalan-Vitalac, France), at the recommended rate of $2.5 \%$ in the feed mixture, and the experimental group III (E-III) diet contained added full-fat soybean meal (Table 1). Vitalan contains $85 \%$ extruded linseed, with the remainder being wheat bran and antioxidants.

Table 1. Ingredients and chemical composition of the pig diets (\%)

\begin{tabular}{|c|c|c|c|}
\hline \multirow{2}{*}{ Nutritients } & \multicolumn{3}{|c|}{ Diet } \\
\hline & E-I & E-II & E-III \\
\hline Corn & 46.7 & 50.8 & 51.0 \\
\hline Wheat & 15.0 & 14.0 & 14.0 \\
\hline Full fat soybean meal & - & - & 14.6 \\
\hline Soy meal & 11.5 & 13.0 & 1.0 \\
\hline Sunflower, seed & 7.5 & - & - \\
\hline Wheat bran & 16.2 & 16.5 & 16.2 \\
\hline Linseed preparation & - & 2.5 & - \\
\hline Di-Ca-P & 0.50 & 0.60 & 0.60 \\
\hline Cattle chalk & 1.20 & 1.20 & 1.20 \\
\hline Cattle salt & 0.40 & 0.40 & 0.40 \\
\hline Premix & 1 & 1 & 1 \\
\hline$\Sigma$ & 100 & 100 & 100 \\
\hline \multicolumn{4}{|l|}{ Chemical composition } \\
\hline Moisture & 11.35 & 11.32 & 11.34 \\
\hline Proteins & 14.54 & 14.50 & 14.52 \\
\hline Fat & 5.34 & 4.76 & 5.72 \\
\hline $\mathrm{Ca}$ & 0.67 & 0.68 & 0.67 \\
\hline $\mathrm{P}$ & 0.60 & 0.60 & 0.60 \\
\hline $\mathrm{ME}$ & 13.41 & 13.43 & 13.44 \\
\hline Lys & 0.65 & 0.65 & 0.65 \\
\hline Met+Cyst & 0.48 & 0.47 & 0.47 \\
\hline
\end{tabular}

E-I diet with added sunflower; E-II diet with added linseed; E-III diet with added soybean meal Premix composition (per kg): Vit. A 700000IJ; Vit. D 100000IJ; Vit. E 1200mg; Vit. K3 100mg; B1 200mg; B2 250mg; B6 150mg; B12 1.5mg; Biotin 5mg; Ca-pantothenate 1200mg; Niacine 1500mg; Choline chloride 50000mg; Fe 10000mg; Cu 2000mg; Mn 2500mg; Zn 10000mg; J 90mg; Se 10mg; Co 50mg; Helmox (antioxidant) 10000mg 


\section{Measurements and analyses}

\section{Slaughtering and processing}

At the end of the study, animals were transported to the slaughterhouse, electrically stunned and immediately slaughtered. Subsequently animals were processed using standard industrial techniques. During the first 24 hours post-mortem carcasses were stored in a ventilated cold room at $2^{\circ} \mathrm{C}$.

\section{Chemical methods}

Pig diet samples were taken for determination of fatty acid composition from complete mixtures at the beginning of the study. Meat samples (m. longissimus dorsi pars lumbalis) and fat samples (backfat) were taken from each pig, in all three groups, after slaughtering, processing and chilling of carcasses, for analysis of fatty acid composition and MDA content. Samples $(300 \mathrm{~g})$ were packaged and stored in plastic bags at $-20^{\circ} \mathrm{C}$, until analysis of fatty acids (seven days). Samples for analyses of MDA were stored for 12 months at $-20^{\circ} \mathrm{C}$ and tested after 3, 6, 9 and 12 months. Chemical analyses to determine protein, water, fat and mineral content were conducted according to AOAC methods (1990) [15]. Total lipids for fatty acid determination were extracted from muscle and backfat with hexane/isopropanol mixture by accelerated solvent extraction (ASE 200, Dionex, Germany). After evaporation of solvent until dryness under a stream of nitrogen total lipids were converted to fatty acid methyl esters (FAME) by trimethylsulphonium hydroxide. FAMEs were determined using Shimadzu 2010 gas chromatograph equipped with flame ionization detector (FID) and cianopropyl HP88 capillary column $(100 \mathrm{~m} \times 0.25 \mathrm{~mm} \times 0.20 \mu \mathrm{m})$ [16]. For MDA determination in fat, a TBA test was used, which is based on the spectrophotometric determination of the pink complex formed after reaction of MDA with 2-thiobarbituric acid [17]. The TBA test is used to determine TBA reactive substance (TBARS), and test results are expressed as TBA number [17].

\section{Statistical analyses}

Statistical analysis of the results was conducted using software GraphPad Prism version 5.00 for Windows (GraphPad Software, San Diego CA, USA, www.graphpad. com). All parameters were calculated as means and standard errors of the means for each group of 10 pigs. One-way ANOVA with Tukey's post-hoc test was performed to assess the significance of differences among experimental groups. Values of $P<0.05$ were considered significant.

\section{RESULTS}

\section{Fatty acid composition of the animal diets}

Fatty acid composition of the diets for all three experimental groups of pigs is presented in Table 2. Diet E-II had lower $(P<0.01)$ amounts of SFA and monounsaturated fatty acids (MUFA) (SFA was significantly different compared to E-I and E-III, while MUFA 
was significantly different only compared to E-I), as well as higher $(P<0.01)$ amounts of PUFA (significantly different compared to E-I). Since there were significant differences in the fatty acid content of the diets, this resulted in different $n-6 / n-3$ ratios. The most beneficial n-6/n-3 ratio was established in diet E-II $(5.57 \pm 0.06)$ (the linseed

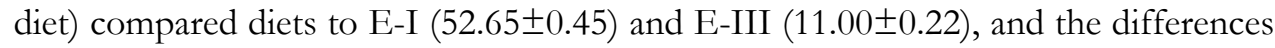
were significant $(P<0.01)$. The fatty acid profiles of pig diets differed according to the ingredients. Diet E-I, with added sunflower, had the highest $(P<0.01)$ content of myristic fatty acid (C14:0) $(0.13 \pm 0.004 \%)$. Diet E-II contained the least $(P<0.01)$ palmitic acid (C16:0) (13.84 $\pm 0.19 \%)$ and stearic acid (C18:0) (3.50 $\pm 0.08 \%)$, while diet E-III, with added soybean meal, had more margaric acid (C17:0) $(0.23 \pm 0.006 \%)$ than diet E-II $(0.17 \pm 0.004 \%)$. Diet E-I did not contain this saturated fatty acid. As expected, diet E-II, the linseed diet, contained more ALA $(8.53 \pm 0.091 \%)$ compared to diets with sunflower (E-I) and soybean meal (E-III) (0.81 $\pm 0.006 \%$ and $4.54 \pm 0.091 \%$, respectively).

Table 2 . Fatty acid levels and ratios in the pig diets (\% of total fatty acids; mean \pm standard error)

\begin{tabular}{|c|c|c|c|}
\hline \multirow{2}{*}{ Parameter } & \multicolumn{3}{|c|}{ Diet } \\
\hline & E-I & E-II & E-III \\
\hline SFA & $20.60^{A} \pm 0.19$ & $18.38^{\mathrm{AB}} \pm 0.24$ & $20.17^{\mathrm{B}} \pm 0.13$ \\
\hline MUFA & $35.29^{\mathrm{AB}} \pm 0.23$ & $25.46^{\mathrm{A}} \pm 0.11$ & $25.51^{\mathrm{B}} \pm 0.13$ \\
\hline PUFA & $43.54^{\mathrm{AB}} \pm 0.31$ & $55.99^{A} \pm 0.28$ & $54.33^{\mathrm{B}} \pm 0.19$ \\
\hline$n-6$ & $42.73^{\mathrm{AB}} \pm 0.31$ & $47.46^{\mathrm{AC}} \pm 0.25$ & $49.79^{\mathrm{BC}} \pm 0.17$ \\
\hline $\mathrm{n}-3$ & $0.81^{\mathrm{AB}} \pm 0.006$ & $8.53^{A C} \pm 0.09$ & $4.54^{\mathrm{BC}} \pm 0.09$ \\
\hline$n-6 / n-3$ & $52.65^{\mathrm{AB}} \pm 0.45$ & $5.57^{A C} \pm 0.06$ & $11.00^{\mathrm{BC}} \pm 0.22$ \\
\hline C14:0 & $0.13^{\mathrm{AB}} \pm 0.004$ & $0.09^{\AA} \pm 0.004$ & $0.09^{\mathrm{B}} \pm 0.003$ \\
\hline $\mathrm{C} 16: 0$ & $14.59^{\mathrm{A}} \pm 0.12$ & $13.84^{\mathrm{AB}} \pm 0.19$ & $14.62^{\mathrm{B}} \pm 0.10$ \\
\hline C17:0 & nd & $0.17 \pm 0.004$ & $0.23 \pm 0.006$ \\
\hline C18:0 & $4.52^{\mathrm{A}} \pm 0.11$ & $3.50^{\mathrm{AB}} \pm 0.08$ & $4.38^{\mathrm{B}} \pm 0.06$ \\
\hline C20:0 & $0.39 \pm 0.006$ & $0.38 \pm 0.008$ & $0.38 \pm 0.006$ \\
\hline C22:0 & $0.68^{\mathrm{AB}} \pm 0.011$ & $0.22^{\mathrm{AC}} \pm 0.006$ & $0.30^{\mathrm{BC}} \pm 0.006$ \\
\hline C24:0 & $0.28^{\mathrm{AB}} \pm 0.006$ & $0.18^{\mathrm{Aa}} \pm 0.006$ & $0.16^{\mathrm{Ba}} \pm 0.004$ \\
\hline C16:1 & $0.08^{\mathrm{A}} \pm 0.004$ & $0.06^{\mathrm{A}} \pm 0.004$ & $0.07 \pm 0.003$ \\
\hline C18:1 cis 9 & $34.88^{\mathrm{AB}} \pm 0.22$ & $25.40^{\mathrm{A}} \pm 0.10$ & $25.44^{\mathrm{B}} \pm 0.13$ \\
\hline C20:1 & $0.32 \pm 0.008$ & nd & nd \\
\hline C18:2 n-6 & $42.33^{\mathrm{AB}} \pm 0.31$ & $47.09^{\mathrm{AC}} \pm 0.25$ & $49.62^{\mathrm{BC}} \pm 0.17$ \\
\hline C20:2 n-6 & nd & $0.09 \pm 0.001$ & $0.04 \pm 0.001$ \\
\hline C20:3 n-6 & $0.40^{\mathrm{AB}} \pm 0.006$ & $0.28^{\mathrm{AC}} \pm 0.006$ & $0.13^{\mathrm{BC}} \pm 0.005$ \\
\hline C18:3n-3 & $0.81^{\mathrm{AB}} \pm 0.006$ & $8.53^{\mathrm{AC}} \pm 0.091$ & $4.54^{\mathrm{BC}} \pm 0.091$ \\
\hline
\end{tabular}

E-I diet with added sunflower; E-II diet with added linseed; E-III diet with added soybean meal; SFAsaturated fatty acids; MUFA- monounsaturated fatty acids; PUFA- polyunsaturated fatty acids; A, B, C Means within row with same superscripts differ significantly at $P<0.01$; ${ }^{a}$ Means within row with same superscripts differ significantly at $P<0.05$; nd - not detected; Percentage are means of values derived from 10 pigs 


\section{Chemical composition of meat}

The chemical composition (protein, total lipids, water and minerals) of the meat is shown in Table 3. Protein in meat samples from E-I animals was $20.49 \pm 0.15 \%$, $20.59 \pm 0.11 \%$ in meat from E-III animals, and $20.72 \pm 0.28 \%$ in meat from E-II animals. The fat content was the lowest in E-II animals $(5.83 \pm 0.31 \%)$, while in E-I and E-III animals it was $6.00 \pm 0.05 \%$ and $6.28 \pm 0.17 \%$, respectively. The water content in meat samples from the three groups was approximately the same and ranged from $72.13 \pm 0.19 \%$ (E-III animals) to $72.38 \pm 0.12 \%$ (E-I animals), while mineral levels were equal in meat from all three groups $(1.13 \pm 0.007 \%)$. The chemical composition (protein, water and fat) of meat from different groups of pigs was not significantly different $(P>0.05)$.

Table 3. Chemical composition of meat from pigs fed on three different diets (mean \pm standard error)

\begin{tabular}{lccc}
\hline \multirow{2}{*}{ Parameter (\%) } & \multicolumn{3}{c}{ Diet } \\
\cline { 2 - 4 } & E-I & E-II & E-III \\
\hline Proteins & $20.49 \pm 0.15$ & $20.72 \pm 0.28$ & $20.59 \pm 0.11$ \\
Water & $72.38 \pm 0.12$ & $72.31 \pm 0.18$ & $72.13 \pm 0.19$ \\
Fat & $6.00 \pm 0.05$ & $5.83 \pm 0.12$ & $6.28 \pm 0.17$ \\
Minerals & $1.13 \pm 0.009$ & $1.13 \pm 0.007$ & $1.13 \pm 0.007$ \\
\hline
\end{tabular}

E-I pigs fed diet with added sunflower; E-II pigs fed diet with added linseed; E-III pigs fed diet with added soybean meal; Percentage are means of values derived from 10 pigs

\section{Fatty acid composition of meat and backfat}

The fatty acid composition of meat and backfat is presented in Tables 4 and 5 , respectively. The average content of SFA and MUFA in the meat and backfat was significantly higher $(P<0.01)$ in pigs fed the diet with added linseed (E-II) (37.91 $\pm 0.31 \%$ of SFA and $43.71 \pm 0.11 \%$ of MUFA in meat; $33.16 \pm 0.21 \%$ of SFA and $44.42 \pm 0.11 \%$ in fat), compared to the pigs fed the diet with added sunflower seed (EI) $36.98 \pm 0.10 \%$ of SFA and $39.59 \pm 0.05 \%$ of MUFA in meat; $30.61 \pm 0.14 \%$ of SFA and $42.64 \pm 0.14 \%$ of MUFA in backfat) and pigs fed the diet with added soybean meal (E-III) (41.42 $\pm 0.002 \%$ of MUFA in meat; $41.91 \pm 0.19 \%$ of MUFA in backfat; SFA of E-III also was higher but without significance $P<0.05)$. Diet with added linseed (E-II) caused a significantly lower $(P<0.01)$ PUFA content in the meat and backfat of the animals $(17.99 \pm 0.18 \%$ in meat; $22.05 \pm 0.19 \%$ in backfat) compared to PUFA content in the tissues of pigs fed other diets (sunflower; $23.17 \pm 0.12 \%$ in meat; $26.69 \pm 0.08$ in backfat and soybean meal; $20.87 \pm 0.003 \%$ in meat; $26.32 \pm 0.16 \%$ in backfat). Meat from the E-II pigs contained significantly less LA $(15.13 \pm 0.11 \%$; $P<0.01)$ and more ALA $(1.07 \pm 0.008 ; P<0.01)$ than pigs fed the other diets. The highest content of $n-6$ fatty acids in both, muscle and backfat, was observed in pigs fed diet with sunflower $(22.53 \pm 0.12 \%$ in meat; $25.75 \pm 0.08 \%$ in backfat), while the highest content of $n-3$ fatty acids $(1.23 \pm 0.013 \%$ in meat; $1.97 \pm 0.04$ in backfat), as well as the lowest $n-6 / n-3$ 
ratio $(13.67 \pm 0.03$ in meat; $10.23 \pm 0.23$ in backfat $)$ was seen in pigs fed diet with added linseed.

Table 4. Fatty acid composition and ratios of meat ( $\%$ of total fatty acids; mean \pm standard error)

\begin{tabular}{|c|c|c|c|}
\hline \multirow{2}{*}{ Parameter } & \multicolumn{3}{|c|}{ Diet } \\
\hline & E-I & E-II & E-III \\
\hline SFA & $36.98^{\mathrm{A}} \pm 0.10$ & $37.91^{\mathrm{A}} \pm 0.31$ & $37.54 \pm 0.002$ \\
\hline MUFA & $39.59^{\mathrm{AC}} \pm 0.05$ & $43.71^{\mathrm{AB}} \pm 0.11$ & $41.42^{\mathrm{BC}} \pm 0.002$ \\
\hline PUFA & $23.17^{\mathrm{AC}} \pm 0.12$ & $17.99^{\mathrm{AB}} \pm 0.18$ & $20.87^{\mathrm{BC}} \pm 0.003$ \\
\hline$n-6$ & $22.53^{\mathrm{AC}} \pm 0.12$ & $16.98^{\mathrm{AB}} \pm 0.23$ & $19.76^{\mathrm{BC}} \pm 0.003$ \\
\hline$n-3$ & $0.69^{A C} \pm 0.002$ & $1.23^{\mathrm{AB}} \pm 0.013$ & $1.12^{\mathrm{BC}} \pm 0.009$ \\
\hline$n-6 / n-3$ & $32.40^{A C} \pm 0.21$ & $13.67^{\mathrm{AB}} \pm 0.03$ & $17.84^{\mathrm{BC}} \pm 0.22$ \\
\hline $\mathrm{C} 14: 0$ & $0.90^{\mathrm{A}} \pm 0.004$ & $0.90^{\mathrm{B}} \pm 0.003$ & $0.88^{\mathrm{AB}} \pm 0.003$ \\
\hline C15:0 & $0.06 \pm 0.0003$ & $0.06 \pm 0.0003$ & $0.06 \pm 0.0003$ \\
\hline C16:0 & $22.19^{\mathrm{AB}} \pm 0.04$ & $22.80^{\mathrm{A}} \pm 0.17$ & $22.77^{\mathrm{B}} \pm 0.02$ \\
\hline C17:0 & $0.45^{\mathrm{AB}} \pm 0.004$ & $0.47^{\mathrm{AC}} \pm 0.004$ & $0.51^{\mathrm{BC}} \pm 0.004$ \\
\hline C18:0 & $13.30 \pm 0.07$ & $13.30 \pm 0.21$ & $13.20 \pm 0.02$ \\
\hline C20:0 & $0.11^{\mathrm{AB}} \pm 0.003$ & $0.13^{\mathrm{A}} \pm 0.003$ & $0.13^{\mathrm{B}} \pm 0.002$ \\
\hline C16:1 & $1.32^{\mathrm{AB}} \pm 0.003$ & $1.66^{\mathrm{AC}} \pm 0.007$ & $1.54^{\mathrm{BC}} \pm 0.010$ \\
\hline C18:1cis 9 & $37.49^{\mathrm{AB}} \pm 0.06$ & $40.85^{\mathrm{AC}} \pm 0.11$ & $39.05^{\mathrm{BC}} \pm 0.08$ \\
\hline C20:1 & $0.83^{\mathrm{A}} \pm 0.009$ & $0.99^{\mathrm{AB}} \pm 0.005$ & $0.80^{\mathrm{B}} \pm 0.048$ \\
\hline C18:2 n-6 & $20.93^{\mathrm{AB}} \pm 0.09$ & $15.13^{\mathrm{AC}} \pm 0.11$ & $18.20^{\mathrm{BC}} \pm 0.03$ \\
\hline C20:2 n-6 & $1.02^{\mathrm{AB}} \pm 0.017$ & $0.86^{\mathrm{AC}} \pm 0.017$ & $0.94^{\mathrm{BC}} \pm 0.003$ \\
\hline C20:3 n-6 & $0.59 \pm 0.002$ & $0.62 \pm 0.002$ & $0.63 \pm 0.002$ \\
\hline C18:3 n-3 & $0.62^{\mathrm{AB}} \pm 0.003$ & $1.07^{\mathrm{AC}} \pm 0.008$ & $1.01^{\mathrm{BC}} \pm 0.008$ \\
\hline$C 20: 3 n-3$ & $0.07^{\mathrm{AB}} \pm 0.002$ & $0.14^{\mathrm{AC}} \pm 0.004$ & $0.11^{\mathrm{BC}} \pm 0.003$ \\
\hline $\mathrm{C} 22: 1+\mathrm{C} 20: 4$ & $0.25^{\mathrm{Aa}} \pm 0.004$ & $0.22^{\mathrm{Ba}} \pm 0.011$ & $0.16^{\mathrm{AB}} \pm 0.004$ \\
\hline
\end{tabular}

E-I diet with added sunflower; E-II diet with added linseed; E-III diet with added soybean meal; SFAsaturated fatty acids; MUFA- monounsaturated fatty acids; PUFA- polyunsaturated fatty acids; ${ }^{\mathrm{A}-\mathrm{C}}$ Means within row with same superscripts differ significantly at $P<0.01$; ${ }^{\text {a }}$ Means within row with same superscripts differ significantly at $P<0.05$; Percentage are means of values derived from 10 pigs

\section{Content of malondialdehyde (MDA) in backfat}

Measured malondialdehyde levels in backfat stored at $-20^{\circ} \mathrm{C}$ after 3, 6, 9 and 12 months of storage are shown (Table 6). In our study, after three months of storage, differences between MDA levels in fat derived from E-I and E-II pigs were significant $(P<0.05)$. After 6 months MDA level in fat from E-II pigs were significantly lower $(0.27 \pm 0.02$ $\mathrm{mg} \mathrm{MDA} / \mathrm{kg})$ compared to MDA level in E-I pigs $(0.36 \pm 0.009 \mathrm{mg} \mathrm{MDA} / \mathrm{kg})(\mathrm{P}<0.01)$ and E-III pigs $(0.33 \pm 0.008 \mathrm{mg} \mathrm{MDA} / \mathrm{kg})(P<0.05)$. After nine months, backfat from E-II pigs contained $0.49 \pm 0.001 \mathrm{mg} \mathrm{MDA} / \mathrm{kg}$, which was lower than in backfat from E-I $(P<0.01)$ and E-III pigs $(P>0.05)(0.58 \pm 0.001 \mathrm{mgMDA} / \mathrm{kg}$ and $0.53 \pm 0.001$ 
mgMDA $/ \mathrm{kg}$, respectively). After 12 months of storage lower levels of MDA were measured in backfat from E-II pigs $(0.70 \pm 0.001 \mathrm{mg} \mathrm{MDA} / \mathrm{kg} ; P<0.01)$ compared to E-I and E-III pigs (0.84 \pm 0.001 and $0.79 \pm 0.001 \mathrm{mg} \mathrm{MDA} / \mathrm{kg}$, respectively).

Table 5. Fatty acid composition and ratios of backfat ( $\%$ of total fatty acids; mean \pm standard error)

\begin{tabular}{|c|c|c|c|}
\hline \multirow{2}{*}{ Parameter } & \multicolumn{3}{|c|}{ Diet } \\
\hline & E-I & E-II & E-III \\
\hline SFA & $30.61^{\mathrm{A}} \pm 0.14$ & $33.16^{\mathrm{A}} \pm 0.21$ & $31.30 \pm 0.21$ \\
\hline MUFA & $42.64^{\mathrm{AC}} \pm 0.14$ & $44.42^{\mathrm{AB}} \pm 0.11$ & $41.91^{\mathrm{BC}} \pm 0.19$ \\
\hline PUFA & $26.69^{A C} \pm 0.08$ & $22.05^{\mathrm{AB}} \pm 0.19$ & $26.32^{\mathrm{BC}} \pm 0.16$ \\
\hline$n-6$ & $25.75^{\mathrm{AC}} \pm 0.08$ & $20.09^{\mathrm{AB}} \pm 0.19$ & $24.91^{\mathrm{BC}} \pm 0.18$ \\
\hline$n-3$ & $0.94^{\mathrm{AC}} \pm 0.001$ & $1.97^{\mathrm{AB}} \pm 0.004$ & $1.42^{\mathrm{BC}} \pm 0.006$ \\
\hline$n-6 / n-3$ & $27.30^{\mathrm{AC}} \pm 0.27$ & $10.23^{\mathrm{AB}} \pm 0.23$ & $17.74^{\mathrm{BC}} \pm 0.77$ \\
\hline C14:0 & $0.86^{\mathrm{A}} \pm 0.01$ & $1.09^{\mathrm{AB}} \pm 0.02$ & $0.93^{\mathrm{B}} \pm 0.009$ \\
\hline C16:0 & $0.08^{\mathrm{A}} \pm 0.006$ & $0.15^{\mathrm{AB}} \pm 0.005$ & $0.11^{\mathrm{Ba}} \pm 0.004$ \\
\hline C17:0 & $19.54^{\mathrm{A}} \pm 0.10$ & $21.66^{\mathrm{AB}} \pm 0.18$ & $20.15^{\mathrm{B}} \pm 0.22$ \\
\hline C18:0 & $0.57^{\mathrm{AB}} \pm 0.01$ & $0.92^{\mathrm{AC}} \pm 0.01$ & $0.70^{\mathrm{BC}} \pm 0.01$ \\
\hline C20:0 & $9.43 \pm 0.11$ & $9.23 \pm 0.10$ & $9.29 \pm 0.10$ \\
\hline C22:0 & $0.10 \pm 0.004$ & $0.10 \pm 0.004$ & $0.10 \pm 0.006$ \\
\hline C16:1 & $1.55^{\mathrm{AB}} \pm 0.01$ & $2.55^{\mathrm{AC}} \pm 0.07$ & $1.83^{\mathrm{BC}} \pm 0.04$ \\
\hline C18:1cis 9 & $40.36^{\mathrm{AB}} \pm 0.12$ & $41.35^{\mathrm{AC}} \pm 0.14$ & $39.46^{\mathrm{BC}} \pm 0.16$ \\
\hline C20:1 & $0.73^{\mathrm{AB}} \pm 0.01$ & $0.52^{\mathrm{AC}} \pm 0.01$ & $0.61^{\mathrm{BC}} \pm 0.01$ \\
\hline C18:2 n-6 & $24.63^{\mathrm{AB}} \pm 0.07$ & $19.21^{\mathrm{AC}} \pm 0.19$ & $23.80^{\mathrm{BC}} \pm 0.17$ \\
\hline C20:2 n-6 & $0.90^{\mathrm{A}} \pm 0.006$ & $0.65^{\mathrm{AB}} \pm 0.01$ & $0.89^{\mathrm{B}} \pm 0.01$ \\
\hline C20:3 n-6 & $0.21 \pm 0.007$ & $0.21 \pm 0.006$ & $0.21 \pm 0.006$ \\
\hline C18:3 n-3 & $0.83^{\mathrm{AB}} \pm 0.008$ & $1.76^{\mathrm{AC}} \pm 0.04$ & $1.24^{\mathrm{BC}} \pm 0.05$ \\
\hline$C 20: 3 n-3$ & $0.10^{\mathrm{AB}} \pm 0.004$ & $0.20^{\mathrm{AC}} \pm 0.005$ & $0.17^{\mathrm{BC}} \pm 0.005$ \\
\hline C22:1+C20:4 & $0.45^{\mathrm{AB}} \pm 0.004$ & $0.31^{\mathrm{AC}} \pm 0.005$ & $0.27^{\mathrm{BC}} \pm 0.001$ \\
\hline
\end{tabular}

E-I diet with added sunflower; E-II diet with added linseed; E-III diet with added soybean meal; SFAsaturated fatty acids; MUFA- monounsaturated fatty acids; PUFA- polyunsaturated fatty acids; ${ }^{\text {A-C }}$ Means within row with same superscripts differ significantly at $P<0.01$; Percentage are means of values derived from 10 pigs

Table 6. Malondialdehyde in backfat (mg MDA/kg; mean \pm standard error)

\begin{tabular}{lcccc}
\hline \multirow{2}{*}{ Diet } & \multicolumn{4}{c}{ Month of storage $\mathbf{( m g / k g})$} \\
\cline { 2 - 5 } & $\mathbf{3}$ Months & $\mathbf{6}$ Months & $\mathbf{9}$ Months & 12 Months \\
\hline E-I & $0.14^{\mathrm{a}} \pm 0.006$ & $0.36^{\mathrm{Aa}} \pm 0.009$ & $0.58^{\mathrm{A}} \pm 0.001$ & $0.84^{\mathrm{Ba}} \pm 0.001$ \\
E-II & $0.12^{\mathrm{a}} \pm 0.007$ & $0.27^{\mathrm{Ab}} \pm 0.002$ & $0.49^{\mathrm{A}} \pm 0.001$ & $0.70^{\mathrm{AB}} \pm 0.001$ \\
E-III & $0.13 \pm 0.006$ & $0.33^{\mathrm{ab}} \pm 0.008$ & $0.53 \pm 0.001$ & $0.79^{\mathrm{Aa}} \pm 0.001$ \\
\hline
\end{tabular}

E-I diet with added sunflower; E-II diet with added linseed; E-III diet with added soybean meal; ${ }^{\mathrm{A}, \mathrm{B}}$ Means within column with same superscripts differ significantly at $P<0.01$; ${ }^{\mathrm{a}, \mathrm{b}}$ Means within column with same superscripts differ significantly at $P<0.05$; Percentage are means of values derived from 10 pigs 


\section{DISCUSSION}

Significantly lower amount of SFA and MUFA, and higher amounts of PUFA in the diet with added linseed compared to the diet with sunflower and soybean meal can be explained by the fact that linseed, contained a very high percentage of PUFA, mostly n-3 fatty acids. The fatty acid profiles of pig diets was in accordance with studies that have shown that more than $70 \%$ of the linseed oils are composed of polyunsaturated fatty acids, mainly ALA and LA [18,19]. Because cereal-based diets commonly offered to pigs supplies mainly n-6 and a small amount of n-3 PUFA, manipulation of the fatty acid content in meat and different meat products, in order to increase n-3 fatty acid content has been studied $(20,21)$. Dietary modifications that increased the $n-3$ fatty acids in animals often use whole oilseeds to achieve this [22,23]. Raes et al. (2004) [3] reported that the replacement of whole soybean with extruded linseed or crushed linseed in the finishing diet of Belgian Blue young bulls increased content of ALA. The chemical composition of the meat was in accordance with the conventional chemical composition of the meat presented in the literature $[24,25]$. The PUFA content in any tissue depends on the amount and structure of dietary fat, de novo synthesis of fatty acids, the conversation rate to other fatty acids and metabolites and the proportion of oxidation for energy consumption [26]. Significantly less LA and more ALA in meat from pigs fed the diet with added linseed may be due to the decreased content of $n-6$ fatty acids and increased content of $n-3$ fatty acids in meat and backfat of this group of pigs. Other works have also reported a reduction of $n-6$ fatty acids when pigs were fed diets rich in ALA, probably because LA, the precursor of other n-6 PUFA is not a good competitor for the enzyme systems involved in chain elongation and desaturation when ALA is present in higher amounts. It can be concluded that dietary inclusion of ALA, in the form of linseed, effectively increased the long chain n-3 fatty acids in pig tissues, which is in general in agreement with other studies [26-30]. Increase in n-6 fatty acids in animals tissues were obtained by diets with added sunflower or soybean meal, while increased n-3 fatty acids resulted from linseed in the diet. The highest content of $\mathrm{n}-6$ fatty acids in both, muscle and backfat, observed in pigs fed diet with sunflower, and the highest content of $n-3$ fatty acids, as well as the lowest $n-6 / n-3$ ratio in pigs fed the diet with added linseed, confirms previous studies $[3,8,19,30]$. A number of studies have been conducted on final pig fattening [28,31-35]. Okanović et al. (2010) [36] investigated the impact of diet with added linseed on content of n-3 fatty acids in pork, in pigs with average weight of $110 \mathrm{~kg}$, as in the present study. Diet containing linseed resulted in higher concentrations of $n-3$ fatty acids $(>7 \mathrm{mg} / 100$ $\mathrm{g})$, which the decreased $\mathrm{n}-6 / \mathrm{n}-3$ fatty acid ratio in meat $(<3 \mathrm{mg} / 100 \mathrm{~g})$ making it more desirable for human diets, from the aspect of human health [37]. In the study conducted by Mourot and Hermier (2001) [37] the effect of three different diets (with added fat, rapeseed or linseed oil) on the fatty acid composition of chicken and pork meat was compared. Chicken and pork from broilers and pigs fed the linseed oil diet had the highest content of n-3 PUFA and lowest $n-6 / n-3$ ratio, which is confirmed in our study. In another study, Romans et al. (1995) [38] investigated different durations 
(7, 14, 21 and 28 days before slaughter) of a pig diet containing 15\% linseed. The ALA content of backfat significantly increased, in correlation with time. In the present study, the linseed diet was fed to pigs over the 46 days prior to slaughter, which could explain the high amounts of ALA in both meat and backfat. Wood et al. (1995) [39] found a linear dependence between content of PUFA in diet and in backfat of pigs. Diet-enriched with cereals and oilseeds with a high content of LA and linolenic acids increase PUFA in backfat of pigs [8]. In agreement with this, the results of our study showed that addition of sunflower seed and soybean meal to pig diets increased the amount of PUFA in meat as well as in backfat. In frozen animal tissues, oxidative changes of lipids can occur during storage. Oxidative changes in lipids are connected with the level of malondialdehyde in the tissue. Levels of MDA increased during storage, with acceptable oxidative changes up to six months of storage (taking the marginal value as being the same as for raw meat, $0.5 \mathrm{mg} \mathrm{MDA} / \mathrm{kg}$ ) [40]. Lower levels of MDA in backfat of pigs fed diet with added linseed might be explained by the consequently increasing n-3 fatty acid levels, and decreasing levels of n- 6 fatty acids, the most oxidatively unstable PUFA, because of the three or more double bonds in the chemical structure [29].

In conclusion, addition of either sunflower seed or soybean meal to pig diet resulted in increased PUFA in both meat and backfat derived from the animals. Addition of linseed to the pig diet improved the $n-6 / n-3$ ratio. Importantly, from the nutritional aspect, the present study showed that addition of oilseeds (linseed, sunflower or soybean meal) to pig diet resulted in pork meat and backfat with higher n-3 PUFA levels.

\section{Acknowledgements}

The study was part of project No 31034 "Selected biological hazards to safety/quality of food of animal origin and control measures from the farm to the consumer", funded by the Ministry of Education, Science and Technological Development, Republic of Serbia.

\section{Authors' contributions}

$\mathrm{M} \check{Z} \mathrm{~B}$ defined the research theme and made the design of the experiment, RM formulated the feed mixtures used in the study, ML and MP monitored pig fattening and carried out measurements and sampling on slaughter line, VĐ was involved in analytic analyses of samples and drafted the manuscript, MB and JĐ performed statistical analysis and drafted the manuscript, VĐ, JĐ, MŽB, RM and VT interpreted data and discussed results. All authors read and approved the final manuscript. 


\section{Declaration of conflicting interests}

The author(s) declared no potential conflicts of interest with respect to the research, authorship, and/or publication of this article.

\section{REFERENCES}

1. Sirtori CR, Galli C, Dossier: Polyunsaturated fatty acids in biology and diseases n-3 fatty acids and diabetes. Biomed Pharmacother 2002, 56: 397-406.

2. Losso NJ: Preventing degenerative diseases by anti-angiogenic functional foods. Food Technol 2002, 56, 6: 78-87.

3. Raes K, De Smet S, Demeyer D: Effect of dietary fatty acids on incorporation of long chain polyunsaturated fatty acids and conjugated linoleic acid in lamb, beef and pork meat: a review. Anim Feed Sci Technol 2004, 113, 1: 199-221.

4. Larque E, Demmelmair H, Koletzko B: Perinatal supply and metabolism of long-chain polyunsaturated fatty acids: importance for the early development of the nervous system. Ann N Y Acad Sci 2002, 967: 299-310.

5. Higgs JD: The changing nature of red meat: 20 years of improving nutritional quality. Trends Food Sci Tech 2000, 11, 2: 85-95.

6. Webb EC, O’Neill HA: The animal fat paradox and meat quality. Meat Sci 2008, 80, 1: 28-36.

7. Pereira PMDCC, Vicente AFDRB: Meat nutritional composition and nutritive role in the human diet. Meat Sci. 2013, 93, 3: 586-592.

8. Wood JD, Richardson RI, Nute GR, Fisher AV, Campo MM, Kasapidou E, Enser M: Effects of fatty acids on meat quality: a review. Meat Sci 2003, 66, 1: 21-32.

9. National Academy of Sciences: Dietary reference intakes for energy, carbohydrate, fiber, fat, fatty acids, cholesterol, protein and amino acids; 2005 [http://www. nap.edu]

10. Karolyi D: Polinezasićene masne kiseline u prehrani i zdravlju ljudi. Meso: prvi hrvatski časopis o mesu 2007, 9, 3: 151-158.

11. Kouba M, Mourot J: A review of nutritional effects on fat composition of animal products with special emphasis on n-3 polyunsaturated fatty acids, Biochimie 2011, 93, 1: 13-17.

12. Eastwood L: The nutritional value of flaxseed meal for swine. PhD Thesis 2008, Department of Animal and Poultry Science, University of Saskatchewan, Canada

13. Haak L, De Smet S, Fremaut D, Van Walleghe K, Raes K: Fatty acid profile and oxidative stability of pork as influenced by duration and time of dietary linseed or fish oil supplementation. J Anim Sci 2008, 86, 6: 1418-1425.

14. NRC (National Research Council): Nutrient requirements of swine. Subcommittee on swine nutrition, Committee on Animal Nutrition, National Research Council (10th Revised Ed.). National Academic Press; 1998.

15. AOAC: Official methods of analyses of association of analytical chemist (15th Ed.). Washington DC; 1990.

16. Trbović D, Vranić D, Đinović-Stojanović J, Petronijević R, Milijašević M, MatekaloSverak V, Spirić A: Fatty acid profile of carp fish species from two aquaculture systems, Zbornik predavanja V Međunarodne konferencije "Akvakultura i ribarstvo" 1.-3. juni 2011, Poljoprivredni fakultet, Beograd-Zemun, Srbija; 2011, 80-84. 
17. Tarladgis B, Watts BM, Younathan MT: A distillation method for the quantitative determination of malonaldehyde in rancid foods. J Am Oil Chem Soc 1969, 34: 44.

18. Gunstone F: Oilseed crops with modified fatty acid composition. J Oleo Sci 2001, 50, 5: 269-279.

19. Guillevic M, Kouba M, Mourot J: Effect of linseed diet or a sunflower diet on performances, fatty acid composition, lipogenic enzyme activities and stearoyl-CoA- desaturase activity in the pig. Livest Sci 2009, 124: 288-294.

20. Enser M, Hallett KG, Hewett B, Fursey GA, Wood J, Harrington G: Fatty acid content and composition of UK beef and lamb muscle in relation to production system and implications for human nutrition. Meat Sci 1998, 49: 329-341.

21. Tešić M, Baltić M, Teodorović V, Nedić D, Mirilović M, Marković R, Aleksić-Agelidis A: Effect of various meal compositions on production results, economic performance and fish meat quality. Acta Vet 2014,64, 3: 338-348.

22. Nieto G, Ros G: Modification of Fatty Acid Composition in Meat through Diet: Effect on Lipid Peroxidation and Relationship to Nutritional Quality - A Review. Chapter 12; 2012 [http://dx.doi.org/10.5772/51114]

23. Tous N, Lizardo R, Vila B, Gispert M, Font-i-Furnols M, Esteve-Garsia E: Effect of a high dose of CLA in finishing pig diets on fat deposition and fatty acid composition in intramuscular fat and other fat depots. Meat Sci 2013, 93: 517-524.

24. Lawrie RA: Meat Science, 5th Ed. Oxford, United Kingdom, Pergamon; 1991.

25. Adamović I, Vitorović D, Blagojević M, Nešić I, Brkić Z: Histological and histochemical properties of $\mathrm{m}$. semitendinosus in German landrace pigs and birth and market weight. Acta Vet 2014, 64, 3: 319-326.

26. Nuernberg K, Fischer K, Nuernberg G, Kuechenmeister U, Klosowska D, EliminowskaWenda G, Fiedler I, Ender K: Effect of dietary olive and linseed oil on lipid composition, meat quality, sensory characteristics and muscle structure in pigs. Meat Sci 2005, 70: 63-74.

27. Cunnane SC, Stitt PA, Ganguli S, Armstrong JK: Raised omega-3 fatty acid levels in pigs fed flax. Can J Anim Sci 1990, 70: 251-254.

28. Matthews KR, Homer DB, Ties F, Calder PC: Effect of whole linseed (Linum usitatissimum) in the diet of finishing pigs on growth performance and on the quality and fatty acid composition of various tissues. Br J Nutr 2000, 83: 637-643.

29. Sheard PR, Enser M, Wood JD, Nute GR, Gill BP, Richardson RI: Shelf life and quality of pork and pork products with raised n-3 PUFA. Meat Sci 2000, 55: 213-221.

30. Kouba M, Enser M, Whittington F, Nute GR, Wood JD: Effect of a high- linoleic acid diet on lipogenic enzyme activities, fatty acid composition, and meat quality in the growing pig. J Anim Sci 2003, 81: 1967-1979.

31. Fontanillas R, Barroeta A, Baucells MD, Guardiola F: Backfat fatty acid evolution in swine fed diets high in either cis-monounsaturated, trans, or (n-3) fats. J Anim Sci 1998, 76: 10451055.

32. Enser M, Richardson RI, Wood JD, Gill BP, Sheard PR: Feeding linseed to increase the n-3 PUFA of pork: fatty acid composition of muscle, adipose tissue, liver and sausages. Meat Sci 2000, 55: 201-212.

33. Thacker P, Racz V, Soita H: Performance and carcass characteristics of growing finishing pigs fed barley-based diets supplemented with Linpro (extruded whole flaxseed and peas) or soybean meal. Can J Anim Sci 2004, 84: 681-688. 
34. Vaclavkova E, Bečkova R: Effect of linseed in pig diet on meat quality and fatty acid content, Arch Tierz Dummerstorf 50 Special Issues 2007: 144-151.

35. Raj S, Polawska E, Skiba G, D Weremko, Fandrejewski H, Skomial J: The influence of dietary source of fatty acids on chemical composition of the body and utilization of linoleic and linolenic acids by pigs. Anim Sci Pap Rep 2010, 28, 4: 355-362.

36. Okanović Đ, Ilić N, Ivanov D, Palić D, R Drobnjaković, Vukčević Č, Ikonić P: Influence of linseed enriched diet on omega-3 fatty acids content in pork. Krmiva 2010, 52: 189-194.

37. Mourot J, Hermier D: Lipids in monogastric animal meat. Reprod Nutr Dev 2001, 41: 109-118.

38. Romans J, Wulf D, Johnson R, Libal G., Costello W: Effects of ground flaxseed in swine diets on pig performance and on physical and sensory characteristics and omega-3 fatty acid content of pork. II. Duration of 15\% dietary flaxseed. J Anim Sci 1995, 73: 1987-1999.

39. Wood JD: The influence of carcass composition on meat quality. In: Quality and Grading of Carcass of Meat Animals. Florida, USA, CRC Press Raton; 1995: 131-155.

40. Lanari MC, Schaefer DM, Scheller KK: Dietary vitamin E supplementation and discoloration of pork bone and muscle, following modified atmosphere packaging. Meat Sci 1995, 41, 3: 237-250.

\section{UTICAJ SUNCOKRETA, LANA I SOJE U ISHRANI SVINJA NA MASNOKISELINSKI SASTAV I OKSIDATIVNU STABILNOST MESA I MASNOG TKIVA}

ĐORĐEVIĆ Vesna, ĐORĐEVIĆ Jasna, MARKOVIĆ Radmila, LAUDANOVIĆ Milica, TEODOROVIĆ Vlado, BOŠKOVIĆ Marija, PEURAČA Mile, BALTIĆ Ž. Milan

Cilj istraživanja je ispitivanje uticaja različitih izvora masti u ishrani tovnih svinja na hemijski i masnokiselinski sastav mesa i masnog tkiva i oksidativnu stabilnost masnog tkiva. Ogled je izveden na 30 svinja, podeljenih u tri grupe, po deset životinja. Ogled je trajao 46 dana do postizanja prosečne telesne mase oko $100 \mathrm{~kg}$. Životinje su hranjene standardnom smešom, sa dodatkom suncokreta (E-I grupa), preparata semena lana u preporučenoj količini od 2,5\% u smeši (E-II grupa) i sojinog griza (E-III). Ispitan je hemijski i masnokiselinski sastav hrane, masnog tkiva i mesa svinja, kao i oksidativna stabilnost masnog tkiva. Prosečan sadržaj zasićenih masnih kiselina (eng. saturated fatty acid- SFA) u smeši sa dodatkom lana bio je statistički značajno manji $(P<0,01)$ od sadržaja SFA u smešama za ishranu druge dve grupe svinja. Prosečan sadržaj mononezasićenih masnih kiselina (eng. monounsaturated fatty acid- MUFA) u smeši za ishranu svinja bio je statistički značajno veći, a polinezasićenih masnih kiselina (eng. polyunsaturated fatty acid- PUFA) statistički značajno manji od sadržaja MUFA, odnosno PUFA u smeši za ishranu svinja druge dve grupe. Između prosečnih sadržaja n-6, odnosno n-3, kao i odnosa n-6/n-3 masnih kiselina u smešama za ishranu svinja utvrđene su statistički značajne razlike $(P<0,01)$. Nisu utvrđene statistički značajne 
razlike u hemijskom sastavu mesa (sadržaj vode, masti, proteina, pepela) poređenih grupa svinja. Prosečan sadržaj SFA i MUFA u mesu i masnom tkivu svinja koje su hranjene smešom sa dodatkom lana bio je satistički značajno veći $(P<0,01)$, a PUFA statistički značajno manji $(P<0,01)$ od sadržaja ovih kiselina u masnom tkivu druge dve grupe svinja. Prosečan sadržaj n-6 masnih kiselina u mesu, kao i u masnom tkivu bio je statistički značajno manji, a n-3 značajno veći u mesu, odnosno masnom tkivu svinja koje su hranjene smešom sa dodatkom lana. Meso i masno tkivo ove grupe svinja imale su i statistički značajno povoljniji odnos n-6/n-3 masnih kiselina. Prosečan sadržaj malondialdehida (MDA) u toku skladištenja zamrznutog masnog tkiva rastao je u svim uzorcima i nakon 12 meseci skladištenja bio je statistički značajno manji $(P<0,01)$ u masnom tkivu svinja koje su hranjene smešom sa dodatkom lana. 